\title{
Maintaining Sustainability of Islamic Microfinance With Outreach and Sharia Compliance in Jambi
}

\author{
Sucipto Djaafar \\ Faculty of Economics and Business \\ Sultan Thaha Syaifuddin Islamic State \\ University \\ Jambi, Indonesia \\ sucipto.djaafar@uinjambi.ac.id
}

\begin{abstract}
This study analises outreach factor which implemanted financial religiusious prinsip in MFIS. Like insurance, mortage and BMT in Jambi. This study also estimates outreach and sharia complemnet on stakeholder of MFIS. Outcome of this study will be contribution to financial management policy in syaria complement of MFIS. Based on the pattern and concept of the outreach of financial institutions that still use aspects that are contrary to shariah principles in the form of determining interest rates. This happened because of the lack of the concept of range that was formulated in the framework of sharia compliance. So that found mismanagement, dysfunctional and moral hazard in Islamic financial institutions in the past 5 years. Seven of Islamic financial institutions in Yogyakarta, 3 Islamic financial institutions in West Java, the ability to reach prospective customers and members shown by the financial institutions, generate large assets but on the other hand compliance with sharia does not become a standard within the reach of institutions.
\end{abstract}

Keywords-Islamic Microfinance, Outreach Microfinance, Performance, Religiusitas, Trust, Staff productivity, Islamic Micro Finance Model.

\section{INTRODUCTION}

MFIS has priority to small group which small scale and large with operational fungcional for funding and distribution and also sharia prinsip [1]. But P. Dewi Setyarini, etc have the fact that MFIS with low performance, only has three aspect,that is the performance of this institution, with main objectives are (1) to analysis the performance (2) lack of morality for occount officer; (3) less of the affectivity as the alternative MFI for coastal community [2].

The lower Performance of MFIS is low in terms of institutional capacity, both for internal conditions and external conditions which are formed by four indicators, namely: first, the quality of human resources which includes the level of formal education and frequency of training, second, market coverage which includes the number of officer, number of creditors and number of debtors, third, product innovation which includes granting credit to micro businesses and women's groups, fourth, operational management which includes operational system procedures and operational management systems [3].

Therefore, there is a need to catalyze growth in the provision of LKS services by strengthening the capacity of potential clients to be able to access LKS services. This can be facilitated through support for mutually reinforcing fields as follows: 1) creating a conducive policy environment, 2) developing critical financial infrastructure, 3) developing viable MFIs, 4) Pro-poor financial technology innovations, 5) intermediation social [4].

The amount of credit in Islamic MFIs does not reach more than the maximum financial needs for small communities as many studies that find the micro scale of Islamic MFIs only range from less than 500 million. According to Lincolin Arsyad, MFIS in Indonesia amounted to 3,043 with spread throughout Indonesia [5]. Therefore, the need for a Sharia Supervisory Board (DPS) that is professional, accountable and has sharia integration to avoid moral hazard, operational dysfunction and inaccuracies in LKS. These needs are used in the aspect of religiosity institutional reach. The range of worksheets that have a strong root and basis in the form of contract religiosity is offered. Such coverage should be supported to develop LKS with the full availability of professional SDIs who have integrity, competence and NON BANK LKS who have the basic trust.

But there are cases of moral hazard that are related to the failure of the LKS as happened in BMT Jami 'Insan Mulia (JIM). This fact confirms the need for supervision on BMTs that generate billions of Rupiah so that they can avoid this fact. The BMT has not been able to function optimally as consumer financing has a clear market share for people who expect usury-free financing institutions, the influence of BMT management is not Professionals are still individualistic mentality (human error), not oriented to the common interests of joint welfare, guidance and supervision of BMTs is more pressing on its existence, not on the utilization of business capital and business culture (corporarate culture). If the LKS starts to be able to raise capital in large enough amounts, there is a tendency for corruption, by utilizing LKS capital for private companies. The stability of LKS conditions can be seen from the success of managing and managing its operations.

At present, the euphoria of the phenomenon of establishment and development of worksheets which is very easy causes there are not a few LKS that do not operate optimally or stagnant or even collapse. As evidenced recently, with the existence of 7 BMTs, it was suspected of having problems in Sleman Regency. This was stated in a workshop on Cooperative Development and Empowerment. 
He also said "some cooperatives on behalf of BMT and this problematic become its own problematic for BMT," Among problematic BMTs related to missmanagement, dysfunctionalization of the role of the Sharia Supervisory Board, looser government oversight, and operational instability of the BMT itself.

Likewise, the findings of Thomas Dichter and Malcolm Harper found that of around 10,000 MFIs worldwide, it is estimated that only 3 to 5 percent have achieved financial self-sufficiency [6]. A very important aspect to consider when looking at the rather small number of surviving MFIs is the size of these institutions. On average, a sustainable MFI is much larger than sustainable and to get a clear picture it is necessary to consider the number of borrowers or portfolio size [7]. Hulme and Mosely (1996) argue that there is an inverse relationship between financial reach and sustainability, an MFI that can reach every community service need with a higher transaction cost to obtain information about the creditworthiness of clients [8].

Abdul Ghafar Ismail and Widiyanto Mislan Condro (2008) measured the level of BMT's outreach for small businesses [9]. Lincolin Arsyad (2008) found that the development of financial institutions can be done from the external and internal aspects of LKS. Whereas Niels Hermes, Robert Lensink and Aljar Meesters (2011) found the internal aspects of the development of financial institutions were lower average loan balances (outreach size and more female borrowers as less efficient clients).

In addition to the MFI's outreach, subsidies also have an impact on sustainability, Hudon and Traca (2011) conclude that subsidies for MFIs do not have to compromise the efficiency of MFIs, provided the subsidy level remains moderate, the findings of Wydick et al. (2011) rather than expecting subsidies from third parties such as the government and the private sector, it is better to focus on the use of existing social networks, so that it will strengthen the relationship between the existence of MFIs and the potential network of new microfinance customers.

Recent research on the extent and effect of finding a gap where research has been more emphasis on the reach of MFIs, such as Hermes et al. (2011), Cull et al., (2011), Valentina Hartarska, Xuan Shen, Roy Mersland (2012), FK Aveh, RY Krah, PS Dadzie (2012), Nara Hari Dhakal (2013) revealed that the future focus of the MFI is on the balance between reach and sustainability. according to Lepi Tarmizi (1997) and Besse Wediawati Research (2003) the weakness of the human resource productivity of Islamic MFIs based on the level of efficiency of the performance of the Institute. This finding shows the impact on the reach of financial institutions.

In addition to the capital problem, the condition of Islamic MFIs also has entity problems, where the sharia identity of MFIs that have not been able to increase trust. The potential of the Jambi religious religiosity as Mulya Siregar's findings concluded that more than $50 \%$ of respondents chose to become partners of Islamic MFIs in Jambi Province [10], choosing sharia LKM does not mean accessing sharia microfinance services, because of customer typologies Financial institutions both micro and banks emphasize economic rationale and lack emotional economy as Mukhlis (2012) describes the behavior of people saving in Islamic banking in central Java.

Valentine Hartarska, et al with the nonstructural approach and performance ratio measurement of MFIs using nonparametric efficiency analysis (DEA), MFI efficiency is calculated based on profitability, efficiency and productivity ratios [11]. It is not only MFI's efficiency that affects performance, but also the MFI's reach which refers to the ability to provide financial services to a large number of customers. Schreiner insists that reach has social benefits for MFIs in helping to improve the welfare of the poor.

Likewise, LKS does not only provide direct financial services to the real sector through fund management as well as Islamic MFIs. MFIS has general advantages and advantages, one side of MFS as a financial service provider on the other hand it also attracts profit for development, meaning that not only performance and excellence factors but also profitability affect the development [12]. Theoretically, the financing coverage factor influences financially and institutionally, but most MFIs, Islamic banks, BPRS, Islamic finance companies face problems regarding the sustainability of their activities. The inability of these institutions can be caused by various main factors such as (1) dependence on support, both from the government and donors; (2) only a project designed for a while; (3) the absence of an adequate microfinance system, and (4) the inability to adapt to the existing microfinance market situation.

\section{LITERATURE REVIEW}

The reach of Islamic Financial Institutions is interesting to observe, observe and develop. Important issues in literacy that have 3 conditions as according to Schreiner microfinance institutions must be able to achieve 1) Financial selfsustainability in the form of profits or profits, 2) financial self-sustainability can survive in the long run only if the structure of rules, incentives, 3) stakeholder organization systems easily adapt to market changes. Ganka Daniel Nyamsogoro (2010) in the outreach approach emphasizes the measurement of Subsidy Dependence Index (SDI) so that the customer reach target is measured by the reach index to evaluate the target customers and the quality of services offered [13].

The range measurement formulated by Vijay Mahajan and G Nagasri in "Financial Services for the Rural Poor and Women in India: Access and Sustainability" explains the sustainability of MFIs based on the ability to receive subsidies and distribute subsidies received from third parties such as government and the private sector. The reach of the Institution is not only limited to indicators and internal institutional factors as Muhammad Adnan and Ely Siswanto found out that the reach can be built from social contracts in MFI customer relations with the principles of kinship and 
mutual cooperation in operations and human resource productivity in Sharia Institutions [14].

Human resource productivity, according to Ely Siswanto, is managerial improvement and financial management that will affect BMT efficiency in credit financing for small and medium sectors [15], further related to financial performance, Camilla Janner Lislevand (2012) found that most MFIs were much leveraged. Because of total short-term debt to assets and debt to assets has a positive and significant effect on the cost of funds. Long-term debt to assets also has a positive impact on the cost of funds, but the relationship is not significant. Total debt to long-term assets and debt to assets has a negative and significant effect on return on assets. Short-term debt to assets also has a negative effect on asset returns, but the relationship is not significant [16].

Recent research on the reach of MFIs concludes that the balance of reach and sustainability in each MFI's operations. The reach of an MFI provides more economic benefits from the business aspect, because after an evaluation of the Subsidies Dependency Index (SDI), it shows a downward trend in subsidies, even though at a slower rate than most MFIs that continue to rely on subsidies for a long time. Technique The analysis used is the Multiple factor technique to establish a formal relationship between each independent variable and the dependent variable, thus proving i. the significance of operational self-sufficiency variable (OSS) in the loan drop-out rate and average loan. ii. self-sufficiency helps the MFI to reduce drop-out rates to increase the value of the reach and obtain additional income from loans, SDI can help the MFI to cover operational costs and justify the hypothesis that there are significant differences in the MFI's OSS and significant differences between OSS and its predictors [17].

M Nadiya, Francisco Olivares-Polanco and T Radha Ramanan (2013) concluded the factors that influence the operational independence (OSS) of Indian Microfinance Institutions (MFIs) using multiple regression analysis, namely income factors, cost efficiency factors and growth factors have a positive influence towards OSS MFIs in India, while the development factor is seen as having a negative influence on the Indian LKM OSS. Five (5) important factors for MFI managers in India in increasing organizational selfsufficiency (OSS) and then found mismanaging of five (5) factors that could deviate from the MFI's goal of poverty alleviation [18]. Robert Cull, Asli Demirgu Kunt and Jonathan Morduch emphasized that there is strong evidence for a trade-off between the influence of the reach on sustainability, where the goal for sustainability does not endanger the MFI's social goals [19]. The balance of coverage measured by subsidies to improve the operational efficiency of the MFI, but the relationship of the measured coverage based on subsidies is not significant, if the subsidy is measured based on the ratio of debt to equity and MFI performance then the subsidy does not have to compromise with the efficiency of the MFI as found in Hudon and Traca's research (2011), according to him the level of subsidies remains moderate, in particular, subsidies are given to improve the performance of MFIs. whereas Wydick et al. (2011) focus on the use of social networks for new microfinance customers, family and neighbor networks as a low-cost strategy to increase the MFI's reach to new customers [20].

Bereket Zerai and Lalitha Rani (2012) emphasize the balance of the reach and sustainability of MFIs, according to him the majority of literature related to the objectives of microfinance institutions (MFIs) reviews financial sustainability, while MFI studies that have an impact on poverty reduction are almost non-existent. Therefore, it is necessary to study the MFI's tradeoff between the reach of the poor and financial sustainability. In terms of research findings do not support a balance between financial reach and sustainability, more specifically the simple correlation between average loan sizes (proxies for reach depth) and operational sustainability are found to be weak. In addition, the correlation between the number of female borrowers (as an alternative proxy for outreach variables) and operational sustainability is also very weak. However, research shows that there is a strong positive correlation between the number of active borrowers (the extent of coverage) and operational sustainability [21].

While the breadth of coverage and sustainability go hand in hand, not for depth of reach and sustainability, it implies that the reach of MFIs can be improved through financial sustainability. Nara Hari Dhakal (2013) shows that the simple correlation between average loan size and operational and financial sustainability is very weak, but there is a strong positive correlation in the relationship between the number of active borrowers (wide coverage) and operational and financial self-sufficiency (sustainability) [22].

In addition, Niels Hermes, Robert Lensink and Aljar Meesters (2011) found evidence that shows that MFIs that have more female borrowers as clients (again the size of the depth of coverage) are less efficient. The stochastic frontier analysis is used to test whether there is a balance between reach to the poor and the efficiency of microfinance institutions (MFIs). There is convincing evidence that the range is negatively related to the efficiency of the MFI. More specifically, this finding explains that MFIs with lower average loan balances (measures of depth of outreach) are also less efficient [23].

Valentina Hartarska, Xuan Shen, Roy Mersland support a balance between reach and sustainability. Microfinance Institutions (MFIs) are evaluated using a structural approach that also captures the reach of institutions and the goals of sustainability, economies of scale and input price elasticity for loans only and deposits mobilize MFIs with large highquality panel data samples. The results confirm the notion that improvements in efficiency can come from the growth or consolidation of the MFI, as found by significant improvements in results for all of the above scales but the benefits focused on mobilizing MFI deposits [24]. 
Mukhlis in his dissertation on saving behavior that examines religiosity variables finds that the rational-economic mindset of customers who save is traded in sharia, and patterned emotionally-ideologically. However, economical rational customers are more dominant than emotionalideological customers. This means that the variable religiosity does not have an effect on saving behavior [25]. Muhammad Khaleequzzaman, finding Islamic social capital can be formed from trust between institutions and customers. This instrument is an action related to institutions in every socio-economic agent, the basic principles of ukhuwah value (unity) and solidarity between sharia customers and MFIs. Measures that make up trust can help full open information, respect transparency and do not include agent and asymmetric information. Donors and clients (clients) of the MFI will be strengthened by Sharia motivation, namely Fardu kifayah, the value of justice and ihsan behavior. Willingness of resources will probably not get results. But this value can be a spirit for the institution. While the negative impacts of social capital can be avoided such as tadlis, gharar, inefficiency of MFIs, often intentional negligence, distrust, and so on [26].

\section{THEORY AND CONCEPT OF OUTREACH IN ISLAMIC FINANCIAL INSTITUTIONS}

Principles of sharia compliance support of the needs and demands of the community in Sharia microfinance institutions [27]. The sustainability potential of Islamic MFIs consists of: outreach, institutional, various instruments of income and financing, flexibility of credit procedures, provision of small and short-term loans, operational aspects of non-interest financing Sharia system MFIs, and Institution law Microfinance Article 12 [28].

\section{A. Outreach Factor of Islamic Financial Institutions.}

Marguerite S. Robinson emphasized that the reach of microfinance refers to small-scale financial services, especially credit and savings [29]. , Mark Schreiner (1997), Gumel Gambo Babandi (2010) and Jannat Ara Parveen (2009) describe six aspects of outreach, namely: i) Financial institutions that are useful or valuable to customers by having a loan contract time, the amount issued by the Financial Institution and the period of time loan maturity. ii) wide outreach related to female customers as a percentage of total borrowers, having branches in the countryside, maximum size of loans granted [29]. Gumel Bambo babandi the existence of a range of indicators, namely: the number of loans for a number of customers, variations of loan products for customer needs. Criteria for the reach of MFIs are measured by indicators of changes in the number of clients, percentage of female clients, total value of assets, total savings on deposits, value of credit outstanding, average size of savings and time deposits, average size of credit and number of branches [30].

\section{B. Shariah Compliance and sustainability}

The impact of financial globalization and laissez-faire impact on the caution of Islamic finance industry and business players to safeguard aspects of sharia compliance (shariah compliance) as a means of preventing risk and fraud in the real sector. Likewise, challenges to financial product innovation must be done by making adjustments between benefits, community dynamics and global economic conditions. This is applied to prove that Islamic values are able and exist in business competition, trade in the era of modern globalization and maintaining the sustainability of Islamic banking in Indonesia. The compliance function is an ex-ante (preventive) action and step to ensure the policies, provisions, systems and procedures, as well as business activities carried out by the Islamic Bank. For this reason, Islamic Banks must understand all applicable laws and regulations, so that it is the responsibility of each individual from the highest rank, namely the Board of Directors to the lowest ranks of the Bank's employees. Sharia compliance in this study uses a service standard that prohibits and avoids RIBA activities based on time value of money, money as an operational transaction tool on BMT, returns and services, BMT activities with no interest and sharia principles applied to partnership business activities, justice, transparency, and real sector transactions [31].

Shariah compliance means adherence and conformity with the Shariah principles In the context of Islamic financial transactions, this means that all the financial transactions must comply and conform to Islamic law and rules of commercial transactions (ahkam fiqh al-mu amalat). These law and rules on the other hand are derived and deduced from the primary sources of the Shariah (that are Divine in origin), i.e., injunctions of the Quran and the directives and practices of the Prophet s.a.w, normally referred to as the Sunnah; as well as the secondary sources of Shariah that are based on human interpretation and reasoning, whether at the strongest level of ijma' (consensus of all jurists), or in the form of qiyas, istihsan, istishab, istislah etc. [32].

Sharia compliance means compliance and in accordance with sharia principles, in the context of Islamic financial transactions, all financial transactions must comply with and comply with Islamic law and commercial transaction rules (ahkam fiqh al-mu'amalat). Laws and rules on the other hand come from and are inferred from the main sources of Sharia, namely, the Koran and the instructions and practices of the Prophet s.a.w, usually referred to as Sunnah; and secondary sources of Sharia based on human interpretation and reasoning, whether at the strongest level of ijma` (consensus of all jurists), or in the form of qiyas, istihsan, istishab, istislah etc. Saiful Azhar Rosly in his paper explained three parameters to determine sharia compliance, namely maqasid al-shariah, financial reporting, and legal documents (legal documentation of contract) to weigh sharia legitimacy in financial institution instruments. Generally, q aqd is only a parameter of sharia law at the level of supervision [33].

Consistency and stability of Islamic financial institutions implement sharia compliance with four approaches. For example, when a murabahah contract is found, the financial reporting approach shows the ownership rights of banks and financial institutions before the sale of murabahah. Because trading objectives will be recorded as fixed assets in the bank's balance sheet before they are sold. 
After the sale of murabahah, the bank held murabahah receivables instead. The legal documentation approach must clearly transfer ownership from vendors to banks and from banks to customers through ownership registration. The sales contract must provide protection to the customer in the case of the sale and purchase of assets. Likewise the bank must receive protection from the court if the customer fails to pay murabahah debt obligations. Therefore, if a dispute occurs, it can be resolved. The maqasid approach must provide insight into murabahah contracts not adhering to usury values and lifestyle. If usury, through interest-bearing loans and loan responsibilities, murabahah financing is not expected to produce economic buble that leads to a crisis. Usually, the aqad approach in contracts is explicitly far from usury, gambling (maisir) and gharar on the types of commodities traded. However, we may not be able to test, say, ownership risk unless we see a murabahah legal document or account. So it is very important for supervisors to recognize the role of legal documentation and financial reporting for contract approval. Likewise, the impact of transactions in the community must also involve maqasid al-sharia in the examination of contracts. However, based on the concept of sharia compliance developed by Saiful Azhar Rosly above, sharia compliance comes from the cognitive understanding and actions of a person in service to a financial institution, in the religion of one's actions on the basis of religion expressed as a religious. Likewise Weber analyzes social actions in social situations, on that basis, the theory of action of a person will act based on their teachings and ordinary teachings are derived from the scriptures. In Islam the scriptures must be believed as a person's faith, not considered as religious if they do not believe in the scriptures. Similarly Glock and Stark / Djamaluddin Ancok (1989) have formulated religious dimensions namely religious intellect.

Sharia compliance operated in the sharia financial industry is an ex-ante (preventive) action and step to ensure the policies, provisions, systems and procedures and business activities carried out by the Islamic Bank in accordance with Bank Indonesia regulations, DSN fatwas and legislation valid invitation. This is done to control the operations of Islamic banking and make Islamic banks not to get out of their corridors, discipline, and steps to minimize banking risks [34].

Sharia compliance is formed by spirituality and religiosity is in a Muslim, the value derived from one's belief or faith in their religion is socially called a religious community, then proved to have a positive relationship to income and poverty. They also prove economic choices for financial institutions that carry out sharia principles, the impact of the continuity of sharia operations is very urgent for BMT. Impact and influence is not only the performance of Islamic financial institutions, but also in general, this research has affirmed religiosity by placing the continuity of sharia compliance as the basic capital of religiosity which will have an impact on institutions and society in general. This research tries to formulate the continuity of the Islamic system. However, personal and institutional religious attitudes are inseparable from sharia compliance both systems and real practices in the form of staff performance, trust and productivity.

\section{RESULTS AND DISCUSSION}

\section{A. Outreach factor on MFIs in Yogyakarta}

Descriptively the outreach according to Marguerite S. Robinson confirms the quality of MFI services formed from the reach of microfinance refers to a number of small scale financial services, especially credit and savings [34]. Member services have been running covering the percentage of the total target clients served by 20 to more than 500 members, based on these data there is a large gap caused by the proportion of capital and financing that are different.

Collective business linkage as the main principle of non-Bank Institutions will be easily created. The role of the association will be easier to implement and does not overlap with other associations. In addition to reaching the client's target, the range of services to clients for a number of women as a percentage of the total borrower, the number of women as a percentage of total savers, number of staff, number of urban branches or units, number of rural branches or units, ratio of village branches to cities or units, The ratio of savings volume to loan position volume, the use of mobile banking.

The consistency of outreach is supported by the first indicator, the capacity of the institution which is reflected in the ability to manage LKS that is measured based on the capability index, knowledge officer and staff. the two main criteria for Jannat Ara Parveen's reach using the Subsidy Dependence Index (SDI) and the target range of the customer is measured by the reach index to evaluate the customer's target and the quality of services offered.

Second, the quality of human resources is measured by the level of knowledge of management and management, the higher the level of knowledge possessed the better the quality of SDI. Human resources that are on average high school graduates, theoretically this is not sufficient to form professional institutions in the management of Islamic finance in the future. HR quality influences professionalism based on professionalism and trust in the people and the business world.

The main problems with low professionalism will have an impact on the quality produced based on standards. Most employees receive a family approach. This is inseparable from the deprived labor market and is crowded with various groups of job seekers and the culture of society that is beginning to change. The need to provide management experience for management in managing other financial institutions requires a minimum of 4 years or more. But in terms of managerial experience in managing BMT on average 2 years to three years. The participation of management and management in various professionally relevant trainings in a year occurs 2 or 3 times. In addition, the consistency of outreach also requires external support, this support will accelerate and systemize outreach according to needs and expectations, namely: 


\section{1) Market Outreach}

Confirmation of market reach for weak communities and people who are unable to access services of formal financial institutions such as Islamic Banks and commercial banks, or communities that tend to be inactive to seek financial services. So that the BMT that is formed on brand image in the form of LKS service information. Branding image requires strong personnel from account officers (AO) or managers, but from the results of the research, the average Non-bank LKS that has three AO means that for the number of members from 100-500 people, 1 account officer (AO) will serve 30 -150 members. A minimal amount of AO cannot help increase market service coverage with an average loan value also minimal. The results of this study tend to show assets of less than 5 billion / year with the ability to provide services of 2-3 billion. If divided by an average of 200-300 members who will get a loan service of 1-2 million rupiah.

\section{2) Product innovation}

Service coverage will succeed with service product support. However, these products are required to be able to innovate and adapt to market needs, innovating products is not easy to need management capabilities of managers, managers who have extensive knowledge of various trainings are not necessarily able to read what products are innovative and adaptive to market needs. So the urgent need for Islamic MFIs is to create innovative and adaptive products if they do not want to experience an increasing number of members who get services.

\section{3) Operation Management.}

Consistent service coverage will be affected by the Operating Procedure System and Management Operational System. LKS that only has manual and incomplete OPS and MOS. OPS and MOS with on line information systems will affect the completeness of business planning. Today's financial industry needs will not work if OPS and MOS are still manual. The effectiveness and efficiency of reach are not achieved without the help of OPS and SOM that are adaptive to market changes.

The supervisory function that does not take place in a timely manner and on target can affect the internal supervision function. Knowledge of the benefits of both that is not sufficient as a weakness of Non-bank LKS in an effort to reduce fraud and minimize the potential for bankruptcy.

\section{4) Business Plan.}

The consistency of service coverage requires business planning as a business component, determining tactical and strategic policies. as a financial institution cannot plan a business road map. Weaknesses that don't have a business plan are still quite large. The result that will emerge is not having a clear direction in carrying out LKS. Strategic planning and tactics for risk management, capital, cash and accounts receivable require valid data from each section. Besides that, complete information forms accurate data and careful planning.

\section{5) Internal supervision}

Internal supervision within a period of less than 1 year with the discovery of fraud that is financially detrimental but not insolvent. This shows that cheating is not easy to avoid. If the frequency of the supervising officer to the borrowing customer occurs in annual terms, this has an impact on managing the risk of fraud and loss. The application of a risk of $15-20 \%$ indicates that the approach to risk is quite weak. As an approach to members to foster shared expectations and trust as social capital.

6) Capital

a) Commercial business. Capital is determined by inventory costs, cash and receivables. commercial or trade business activities such as Bai Murabaha who use capital are more likely to get sufficient benefits in meeting the needs of the institution. Whereas savings fund collection on average has a large deposit account in more than 100 savings accounts.

b) Subsidies that are not able to meet the needs of commercial or trade businesses in their activities will greatly need subsidies from the government and the private sector. This will result in a level of efficiency.

c) Linkage, Apart from business, subsidies and minimum capital, linkage or business networks in the form of branches and holding companies that will assist in services and promotions.

d) Programs related to the banking world, which have programs that are directly related to the banking world will be able to meet the need for capital.

e) Regional economy, the regional economy in Gross Regional Revenue (GDP), inflation rate, tax incentives and subsidies from the government and other donor agencies is quite influential as it states that it has no effect, states that it is less influential, states that it is quite influential, responds influentially.

\section{B. Sharia complement in MFIs}

The Syariah system is a standard for the development of an institution that operates the basic principles of Islamic finance in which sharia compliance options are operated by services, rules, and ethical values for stakeholders both business people and members and customers. However, the continuity of the sharia system in current research actually shows an influence on the sustainability of institutions, as well as the research of Widiastuti (2003), Mukhlis (2010), Khaled (2011), Khaleequzzaman et al (2012), Rulindo et al (2013), and Muhammad (2014) prove that customers and members comply with sharia. The perpetrators and administrators also operate sharia compliance as evidenced by not operating over the ban on usury activities in obtaining benefits from services and business, but also transparency of services such as partnership practices, justice and prioritizing the real sector from the financial sector. Based on the 
explanation above, it is necessary to emphasize to show the continuity of the sharia compliance system by establishing a system that can measure sharia compliance and at the same time its sustainability.

The various problems and the low level of sharia compliance as a basic system that operates with specific criteria for sharia financial institutions. Sharia compliance categorization in eliminating policies must be motivated by the first, eliminating discriminatory services on financing, discriminatory financing tendencies only for enforcement of sharia compliance, for example meeting customers late in paying installments.

At the beginning of the operation BMT actively invited market traders to become customers. They (BMT) are not too selective in inviting customers, all of them (traders) are invited to become new customers. However, after the new member gets a loan and repays the loan, the member is not supervised in repayment. Members who are not current will be discriminated against for no more loans. Based on the information from Ibu Sri, there were members who were in arrears and did not return loans, the members were no longer given loans. Second, discriminatory attitudes towards members and prospective borrowers occur are affected by conditions, the frequency of discrimination against members with standard terms and service rules are tightened by social contracts between members and LKS. This study produced findings that the lack of strict standards of rules will result in members who feel unbound, as well as prospective members.

However, there are no strict regulatory standards, for the smooth return of financing and borrowing. Many borrower customers are not smooth in returning the financing that has been due. The willingness of prospective members to save but many have not been able to set aside their income in the form of savings. Some only provide easy access to services in the number of loans and there is no increase. Some realize the standard function of the rules in improving the quality of service, but only some do not have a fixed and strict rules standard, because the standard LKS rules often function not standard with manual systems.

Other categories are sharia compliance on transaction services and business services that always adhere to sharia principles, but the need for sharia supervisory boards that operate in transaction contracts is not always monitored so that often causes some to not have DPS. Having DPS is based on managerial needs not to improve sharia compliance.

An ineffective supervision system causes a low frequency of monitoring of the sharia system, sometimes operates and often does not operate according to service, but also due to the frequency of regulatory supervision that operates based on standard rules. The financial side is based on standard rules. However, the supervisory system does not work optimally due to 3 subordinate positions, government, associations and DPS. The three supervisors oversee according to their procedures, do not have the same vision, besides many are also anxious if supervised by many parties, finally supervision does not work effectively. Adequacy of regulations should encourage the adoption of accounting and financial standards well, but often do not apply financial reporting standards. Meanwhile, regulators do not guarantee sharia errors and rule system errors.

Legal uncertainty, rules and regulations foster big problems. Some LKS only comply with and implement the standard rules issued by the DSN Fatwa. Operationally, serving members and prospective borrowers with contracts that are regulated by Islamic sharia. However, there is a lot of evidence of sharia contract mismatches, for example not operating in accordance with sharia, but contract services in accordance with sharia are rare but contract services operate less in accordance with very small sharia principles. Sharia system operations should be appropriate not only for members and prospective members, but also in open information in the form of service certainty for prospective zakat almsgivers. Open information as a strength instrument increases the trust of members, resulting in members' expectations for LKS.

Lack of member information should be demanded by members, but demands for information that is always limited cause some members will use the information available, limited information for members because the service does not prioritize the interests of the information. On the other hand, general information is always given to members through brochures and pamphlets. Open information as a condition of operating in sharia, but most LKS complained about the objection of operational funds that were not sufficient to carry out open information.

Explanations and information about sharia are not important, but the expansion of reach to customer groups in traditional markets is an obligation for staff. Traditional markets have been besieged by financial services both nonsharia and sharia, even now business capital with lending is a topic for some people involved in the market. But the biggest problem for them is helplessness in improving their economic conditions depending on capital loans. It was not only Sharia issues but also not sharia.

Another contributing factor, the service is not operated in a sharia manner is weak supervision of sharia mistakes and errors in services. Supervision is not only carried out in the operational system of sharia, but also supervision in other operational service activities such as reports and application of sharia financial accounting standards. The principle of sharia compliance is carried out on business activities based on sharia principles. Meanwhile, the factor of sharia compliance is also the key to success in carrying out the activities of institutions that have Islamic principles and rules. Service activities that are in accordance with sharia principles often make mistakes in sharia rules. Sharia supervision needs to be done very tightly, this is very urgent in the management of service businesses based on sharia principles and rules. Unfortunately, non bank financial institutions that do not and have never received supervision need to be reviewed by the certification body for the benefit of sharia compliance. 
Information should be given to members and prospective members twice a year, some of which never inform the condition of the institution periodically and a year. The lack of information, the condition of the institution and the disclosure of information result in business confidence and uncertainty. Another consequence is the weakening of the reach, because the most important aspect for Non-Bank LKS is the similarity of open vision, mission, information and cooperation which is undoubtedly integrated in the current non bank MFIs. The principle of sharia in its business transactions and there are those who have not yet implemented sharia principles. Like the financing of buying and selling, sometimes storing goods that are traded. In this case there is an administrative fee that must be charged to the buyer as a cost for security, storage costs, and depreciation costs. At this time it does not carry out the storage of goods so it does not carry out the principle of buying and selling in accordance with the sharia, buying and selling occurs because the goods that will be traded legally belong to the seller. If the item is not stored, it is likely that it will only sell the property of another person, as in textual syariah, it is stated that you do not sell what you do not have.

In this case, buying and selling that does not occur. It is possible that Non-Bank LKS has carried out the role of broker. The profit sharing of mudhorabah is based on the financial report of the prospective mudhorib. Most of the requirements are to minimize the risk of moral hazard in mudhorobah financing. There is still a large lack of understanding of the importance of the customer's financial statements as a basic source in determining to make a hajj. Distribution of financing results has been distorted from the original system as operational. "Different financing or loans between Non-Bank LKS, borrowing 3 million will be returned within 3 months or 100 days, in installments of 15 thousand per day while Islamic funds loaned 3 million at 12 per day while there are weekly payments of 53 thousand rupiah in a week. Payment is different from the administration fees, also different between non bank; there are those that are deducted in advance for 24 thousand administration fees. Meanwhile, it is also applied by not cutting administrative costs. But the addition of daily installments plus savings and the return (profit sharing).

\section{CONCLUSION}

This research found that sustainability of Islamic microfinance in Jambi influenced by outreach factor. The shaping factor for sharia compliance is the suitability of sharia in the system by innovating service patterns that are not only limited to financing members but are able to improve performance and productivity for the sustainability of Islamic microfinances, such as sharia practices in buying and selling which are generally carried out without storage. So currently managers need not only limited knowledge skills but also conceptual skills of a manager. Creativity in the practice of sharia in Islamic microfinances is done by self-understanding of sharia as a cognitive-social understanding. While the prerequisites and conditions for the establishment of sustainability based on the largest contribution factors in reach, trust, staff productivity, and performance of institutions in establishing sustainability and contributing above the value of 0.5 are significant enough to be a prerequisite for sustainability.

Meanwhile, the formation of self-sufficiency in Islamic MFis is operationally shaped by the value of profits, significant business capital, the ability of managers to adapt to market changes, standards, and the structure of Islamic microfinances' financing and the quality of human resources is quite an initial prerequisite for sustainability. Even though the prerequisites have been fulfilled is required; (1) able to increase the reach in the form of clarified benefits of MFIs, branches that do not overlap with other Islamic Financial, because they result in unfair competition. (2) Establishment of Islamic microfinances' performance structure through the creation of regulatory and supervision oversight functions, operational management, business planning, capital, product innovation, religious and community leaders involved, and benefit-oriented and togetherness-oriented associations. (3). The low ability of staff to increase productivity due to the low rights obtained compared to obligations. (4) Trust as a function of reinforcement and social capital for MFIS in carrying out its institutions in the midst of the ummah, increasing professionalism, guaranteeing risk and harmony in self and sharia practices.

\section{REFERENCES}

[1] Martono, "Bank dan Lembaga Keuangan Lain” (Yogyakarta: Ekonisia, 2002), hlm. 2.

[2] Setyarini, P Dewi and Hubeis, Musa "Evaluasi Kinerja Lembaga Keuangan Mikro Swamitra Mina dengan Pendekatan Balanced Scorecard (Studi Kasus di Kabupaten Bantul, Yogyakarta" Studi Kasus, 5, no. 1 (2010): 80-89.

[3] Salam, Abdul "Sustainabilitasn Koperasi Simpan Pinjam Dalam Rangka Peran Keuangan Mikro Bagi Pemberdayaan Masyarakat," 2007.

[4] Sharma, Ashok Developing Sustainable Microfinance," Asian Development Bank: At Www. Unescap. Org/Drpad/Projects/Fin_dev2/Adbsharma. Pdf (21.10. 2003), 2001, 123-36.

[5] Arsyad, Lincolin "Lembaga Keuangan Mikro: Institusi, kinerja dan Sustainabilitas", (Yogyakarta: Penerbit Andi, 2008), hlm. 86.

[6] Dichter, Thomas and Harper, Malcolm "What's Wrong with Microfinance?", Rugby, Warwickshire, Practical Action Publishing, 2007, hlm. 49

[7] Zeller, Manfred and Richard, L, The Triangle of Microfinance: Financial Sustainability, Outreach, and Impact, 2002, doi:10.1093/erae/30.4.567.

[8] Regassa, Dereje and Negash, Rijalu, 2014, Outreach and Financial Performance of Microfinance Institution in Case of Seka Cokorsa Woreda of Jimma Zone, Global Journal of Management and Business Research: C Finance Volume 14 Issue 4, 53-68.

[9] Siwar, Chamhuri Ismail, Abdul Ghafar and Islam, Md . Aminul "Microfinance and Sustainable Livelihood: A Conceptual Linkage of Microfinancing Approaches towards Sustainable Livelihood Abul Bashar Bhuiyan , Institute for Environment and Development ( L" 8, no. 3 (2012): 328-33

[10] Mulya Siregar, "Agenda Pengembangan Perbankan Syariah Untuk Mendukung Sistem Ekonomi Yang Sehat Di Indonesia: Evaluasi, Prospek Dan Arah Kebijakan", dalam IQTISAD Journal of Islamic Economics, Vol. 3, No. 1, Muharram 1423 H/Maret 2002, hlm. 53.

[11] Hartarska, Valentine, Nadolnyak, Dennis and Shen, Xuan "Efisiensi Microfinance Cooperatives, "American Journal of Development Studies, Volume 1, no.2, 2012, hlm. 55-56.

[12] Zerai, Bereket and Rani, Lalitha "Is There a Tradeoff between Outreach and Sustainability of Micro Finance Institution? Evidence 
from Indian Microfinance Institutions (MFIS)," European Journal of Business and Management, Vol. 4, No.2, 2012, hlm. 92.

[13] Parveen, Jannat Ara "Theoretical and Empirical Researches in Urban Management Sustainability Issues of Interest-Free Micro-Finance Institutions In Rural Development And Poverty Alleviation. The Bangladesh PERSPECTIVE,”2008, 112-33.

[14] Adnan, Muhammad "Business Plan Project Pendirian Koperasi Jasa Keuangan Syariah 'Mitra Maju Sejahtera': Rencana Operasional Dan Sumber Daya Manusia" (Universitas Indonesia, 2012).

[15] Siswanto, Ely"Strategi Pengembangan BMT (Baitul Maal WA Tamwil) Dalam Memberdayakan Usaha Kecil Menengah,” dalam http://ejournal.uin-malang.ac.id diakses maret 2013.

[16] Lislevand, Camilla Janner "The Effect of Capital Structure on Microfinance Institutions Performance" (University of Agder, 2012).

[17] Aveh, F K, Krah, R Y and Dadzie, P S "An Evaluation of Sustainability and Subsidy Dependence of Microfinance Institutions in Ghana Sub-Saharan Africa With Specific" 6, no. 1 (2013): 55-63, doi:10.3968/j.ibm.1923842820130601.1090.

[18] Nadiya, M, Olivares-Polanco, Francisco and Ramanan T Radha Dangers in Mismanaging the Factors Affecting the Operational SelfSustainability (OSS) of Indian Microfinance Institutions (MFIs) - An Exploration into Indian Microfinance Crisis, Asian Economic and Financial Review 2, no. 3 (2012): 448-62.

[19] Cull, Robert et al., "Benchmarking the Financial Performance, Growth, and Outreach of Green- Field MFIs in Africa," Emerging Markets Review 25 (2015): 92-124, doi:10.1016/j.ememar.2015.05.002.

[20] Niels Hermes and Robert Lensink, "Microfinance: Its Impact, Outreach, and Sustainability," World Development 39, no. 6 (2011) 875-81, doi:10.1016/j.worlddev.2009.10.021.

[21] Bereket Zerai and Lalitha Rani, "Is There a Tradeoff between Outreach and Sustainability of Micro Finance Institutions? Evidence from Indian Microfinance Institutions (MFIs)," Research Journal of Finance and $\begin{array}{lllll}\text { Accounting } 2, & \text { no. } & 11 & \text { (2012): } & 32-42,\end{array}$ http://iiste.org/Journals/index.php/RJFA/article/view/1291.

[22] Nara Hari Dhakal, "OUTREACH AND SUSTAINABILITY OF NEPALESE MICROFINANCE INSTITUTIONS,” no. January (2013)
23] Niels Hermes, Robert Lensink dan Aljar Meesters, "Outreach and Efficiency of Microfinance Institutions," jurnal World Development, Vol. 39, No. 6, 2011, hlm.938-948.

[24] Valentina Hartarska, Xuan Shen, dan Roy Mersland, "Scale economies..., Hlm. 118-131.

[25] Mukhlis, "Perilaku Menabung di Perbankan Syariah Jawa Tengah", Disertasi Program Studi Doktor (S-3) Ilmu Ekonomi, Universitas Diponegoro, Semarang, 2011, hlm.10

[26] Muhammad Khaleequzzaman, "Islamic Microfinance: An Inclusive Approach with Special Reference to Pakistan", Second European Research Conference on Microfinance June 16 - 18, Groningen, the Netherlands.

[27] Muhammad, Lembaga keuangan syariah, (Yogyakarta: Graha Ilmu: 2007), hlm. 25

[28] Undang-Undang Republik Indonesia Nomor 1 Tahun 2013 Tentang Lembaga Keuangan Mikro

[29] Marguerite S. Robinson, The Microfinance Revolution Sustainable Finance for the Poor Lessons from Indonesia the Emerging Industry (Washington, D.C: 2001), hlm. 9.

[30] Babandi, Gumel Gambo, 2011, "Micro finance institutions in Nigeria outreach and sustainability: Questionnaire survey findings", International Journal of Business and Social Science 2 (9), 126-129.

[31] Muhammad, Tehnik Perhitungan Bagi Hasil di Bank Syariah (Yogyakarta: UII press, 2004)

[32] Engku Ali, Rabiah Adawiah Shariah-Compliant to Shariah-Based Financial Innovation: A Question of Semantics or Progressive Market Differentiation, makalah dipresentasikan pada the 4th SC-OCIS Roundtable, 9 -10 March 2013, Ditchley Park, Oxford, United Kingdom. hlm.4.

[33] Rosly, Saiful Azhar, Shariah Compliant Parameters Reconsidered, International Center for Education in Islamic Finance (INCEIF), Kuala Lumpur, Malaysia, hlm.2-5

[34] Bank Indonesia, Peraturan Bank Indonesia Nomor 13/2/PBI/2011 Tentang Pelaksanaan Fungsi Kepatuhan Bank Umum, Tanggal 12 Januari 2011 